\title{
Critical illness-associated cerebral microbleeds in COVID-19 acute respiratory distress syndrome
}

Octave Cannac, Laurent Martinez-Almoyna, MD, and Sami Hraiech, MD, PhD Neurology ${ }^{\circledR}$ 2020;95:498-499. doi:10.1212/WNL.0000000000010537

Figure Brain MRI

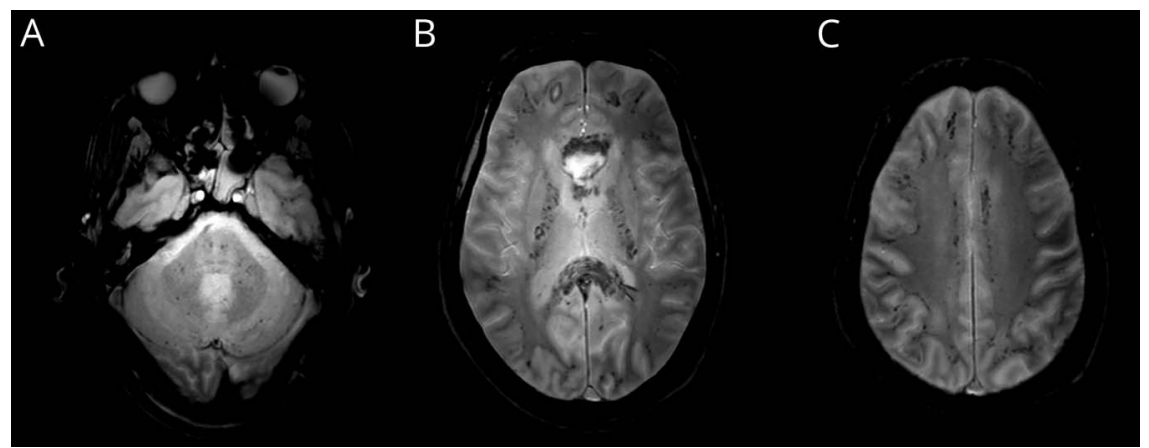

Axial gradient recalled echo T2*-weighted sequence reveals (A) microbleeds scattered in cerebellum and brainstem; (B) innumerable microbleeds predominantly located in corpus callosum and internal capsules, associated with small right juxtacortical frontal hematoma and intracallosal hemorrhage; and (C) countless microbleeds all along the gray/ white matter interface.

A 63-year-old man developed coronavirus disease 2019 acute respiratory distress syndrome requiring mechanical ventilation and extracorporeal membrane oxygenation (ECMO). Brain MRI performed because of delirium revealed callosal and juxtacortical hematomas associated with countless and punctate cerebral microbleeds disseminated in the corpus callosum and along the gray/white matter interface (figure).

This pattern, only detected by blood-sensitive MRI sequences, is typical of critical illnessassociated cerebral microbleeds ( $\mathrm{CI}-\mathrm{aCMB})$, a rare condition reported in patients with acute respiratory failure, requiring mechanical ventilation, and sometimes undergoing ECMO. ${ }^{1}$ Even though the pathophysiologic mechanisms remain unknown (probably related to severe hypoxemia), a relatively high proportion of $\mathrm{CI}-\mathrm{aCMB}$ published cases are induced by influenza. ${ }^{2-4}$ In this patient infected with severe acute respiratory syndrome coronavirus 2 , we postulate a possible contribution of a viral-related endotheliopathy.

\section{Correspondence}

Dr. Martinez-Almoyna

laurent.martinez-almoyna@

ap-hm.fr

\section{MORE ONLINE}

COVID-19 Resources

For the latest articles, invited commentaries, and blogs from physicians around the world NPub.org/COVID19 


\section{Study funding}

No targeted funding reported.

\section{Disclosure}

The authors report no disclosures relevant to the manuscript. Go to Neurology.org/N for full disclosures.

Appendix Authors

\begin{tabular}{lll}
\hline Name & Location & Contribution \\
\hline Octave Cannac & $\begin{array}{l}\text { Hôpitaux } \\
\text { Universitaires de } \\
\text { Marseille }\end{array}$ & $\begin{array}{l}\text { Drafting and revision of } \\
\text { manuscript for intellectual } \\
\text { content }\end{array}$ \\
\hline $\begin{array}{l}\text { Laurent } \\
\text { Martinez- }\end{array}$ & $\begin{array}{l}\text { Hôpitaux } \\
\text { Aniversitaires de } \\
\text { Marseille }\end{array}$ & $\begin{array}{l}\text { Drafting and revision of } \\
\text { manuscript for intellectual } \\
\text { content }\end{array}$ \\
\hline $\begin{array}{l}\text { Sami Hraiech, } \\
\text { MD, PhD }\end{array}$ & $\begin{array}{ll}\text { Hôpitaux } \\
\text { Universitaires de } \\
\text { Marseille }\end{array}$ & $\begin{array}{l}\text { Revision of manuscript for } \\
\text { intellectual content }\end{array}$ \\
\hline
\end{tabular}

\section{References}

1. Fanou EM, Coutinho JM, Shannon P, et al. Critical illness-associated cerebral microbleeds. Stroke 2017;48:1085-1087.

2. Chow FC, Edlow BL, Frosch MP, Copen WA, Greer DM. Outcome in patients with H1N1 influenza and cerebrovascular injury treated with extracorporeal membrane oxygenation. Neurocrit Care 2011;15:156-160.

3. Shah J, Armstrong MJ. Extracorporeal membrane oxygenation: uncommon cause of corpus callosal microhemorrhage. Neurology 2015;84:630.

4. Gijs J, Lambert J, Meyfroidt G, Demeestere J. Cerebral microbleeds and intracerebral hemorrhage associated with veno-venous extracorporeal membrane oxygenation. Acta Neurol Belg 2018;118:513-515.

\section{COVID-19 and Neurologic Disease: Call for Papers!}

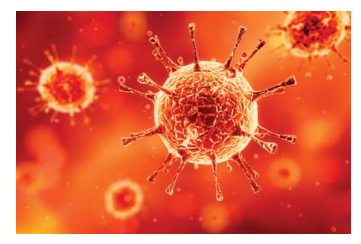

The editors of Neurology are interested in papers that address the neurological aspects of COVID-19 infection and challenges to the management of patients with chronic neurological conditions who have, or are at risk for, the infection. Relevant papers that pass initial internal review will undergo expedited peer review and online publication. We will consider papers posted in preprint servers.

Submit observational studies and clinical trials as Articles and case series and case reports under the Clinical/Scientific Notes category to https://submit.neurology.org/ today!

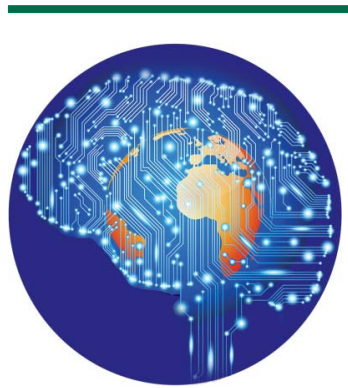

\section{Practice Current: An interactive exchange on controversial topics}

Share your own best practices.

Read commentary with expert opinion.

Explore results on an interactive world map.

NPub.org/NCP/practicecurrent

Neurology ${ }^{\circledR}$ Clinical Practice 


\section{Neurology}

\section{Critical illness-associated cerebral microbleeds in COVID-19 acute respiratory distress syndrome}

Octave Cannac, Laurent Martinez-Almoyna and Sami Hraiech

Neurology 2020;95;498-499 Published Online before print July 29, 2020

DOI 10.1212/WNL.0000000000010537

This information is current as of July 29, 2020

\section{Updated Information \& Services}

References

Citations

Subspecialty Collections

Permissions \& Licensing

Reprints including high resolution figures, can be found at: http://n.neurology.org/content/95/11/498.full

This article cites 4 articles, 2 of which you can access for free at: http://n.neurology.org/content/95/11/498.full\#ref-list-1

This article has been cited by 3 HighWire-hosted articles: http://n.neurology.org/content/95/11/498.full\#\#otherarticles

This article, along with others on similar topics, appears in the following collection(s):

\section{Critical care}

http://n.neurology.org/cgi/collection/critical_care

Intracerebral hemorrhage

http://n.neurology.org/cgi/collection/intracerebral_hemorrhage

MRI

http://n.neurology.org/cgi/collection/mri

Information about reproducing this article in parts (figures,tables) or in its entirety can be found online at:

http://www.neurology.org/about/about_the_journal\#permissions

Information about ordering reprints can be found online:

http://n.neurology.org/subscribers/advertise

Neurology ${ }^{\circledR}$ is the official journal of the American Academy of Neurology. Published continuously since 1951, it is now a weekly with 48 issues per year. Copyright (C 2020 American Academy of Neurology. All rights reserved. Print ISSN: 0028-3878. Online ISSN: 1526-632X.

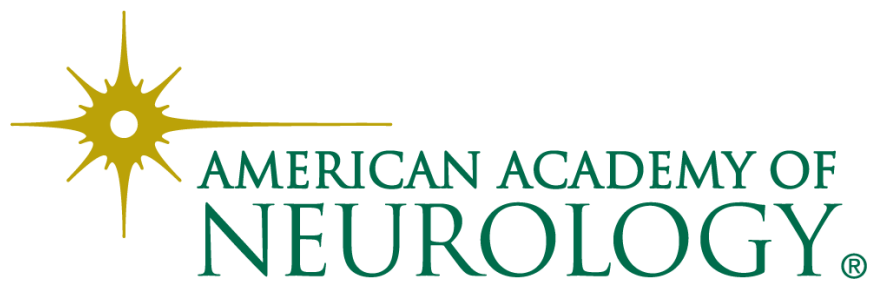

